\title{
KOMUNIKASI KELUARGA DALAM HUBUNGAN JARAK JAUH PADA MAHASISWA PERANTAU DI KOTA LHOKSEUMAWE Cindenia Puspa $\operatorname{Sari}^{1} \&$ Nur Aqila Fitri ${ }^{2}$
}

1. Dosen program studi Ilmu Komunikasi Universitas Malikussaleh

2. Alumni Univeristas Malikussaleh

Email: cindeniapuspasari@unimal.ac.id

\begin{abstract}
ABSTRAK
Penelitian ini berjudul Komunikasi Keluarga Dalam Hubungan Jarak Jauh(Studi Kasus Komunikasi Jarak Jauh Pada Mahasiswa Perantauan di Program Studi Ilmu Komunikasi Angkatan 2014). Penelitian ini bertujuan untuk mengetahui proses komunikasi keluarga yang terjadi antara mahasiswa (anak) dengan orang tua nya dalam hubungan jarak jauh. Penelitian ini menggunakan pendekatan kualitatif yang bersifat deskriptif dengan menggunakan teori skema hubungan keluarga. Untuk memperoleh data dan informasi yang akurat maka metode yang digunakan dalam penelitian ini adalah observasi, wawancara dan dokumentasi. Teknik analisis data yang digunakan dalam penelitian ini adalah reduksi data, penyajian data, dan penyimpulan data. Penelitian ini dilaksanakan di kota Lhokseumawe dan berlangsung selama dua bulan yaitu Mei - Juli 2018. Subjek dalam penelitian ini adalah mahasiswa Universitas Malikussaleh jurusan Ilmu Komunikasi angkatan 2014 yang berasal dari luar kota Lhokseumawe, daerah Aceh Utara. Hasil dari penelitian ini menunjukkan bahwa mahasiswa yang tinggal terpisah dari orang tuanya (perantauan) mereka melakukan komunikasi jarak jauh dengan orang tuanya meskipun terdapat hambatan yang membuat aktifitas komunikasi terganggu dan tidak berjalan dengan baik. Dalam hal berkomunikasi orangtua lebih sering menghubungi anaknya dari pada anak yang menghubungi orangtuanya.Penelitian ini juga menemukan bahwa mahasiswa yang tinggal terpisah dari orangtua ternyata tidak menceritakan semua hal kepada orangtuanya. Hal ini, karena para mahasiswa takut membuat orangtuanya menjadi cemas dan khawatir
\end{abstract}

Kata Kunci: Komunikasi, Keluarga, Hubungan Jarak Jauh.

\section{Pendahuluan}

Perkembangan zaman yang terus berkembang akan mempengaruhi setiap keluarga untuk membentuk anggota keluarga menjadi individu yang cerdas. Karena itu, banyak orang tua yang ingin memberikan pendidikan yang terbaik untuk anak mereka. Para orang tua juga rela terpisah jauh 
dengan anak mereka demi masa depan dan cita-cita yang akan dicapai oleh anak yang mereka cintai.

Perkembangan teknologi dan komunikasi yang juga semakin pesat pada saat ini mempengaruhi komunikasi yang terjalin diantara anggota keluarga. Hal ini dapat dilihat dari munculnya aplikasi dan alat komunikasi yang setiap saat dapat digunakan oleh setiap individu seperti BBM (Blackberry Messenger), Instagram, Whatsapp, dan media komunikasi lainnya. Bagi para orang tua dan anak yang tinggal terpisah, maka perkembangan ini akan membantu mereka untuk menjaga komunikasi diantara orangtua dan anak. Misalnya dengan menggunakan alat komunikasi handphone, para orang tua dapat menghubungi anak mereka setiap saat. Sedangkan jika para orang tua ingin melihat keadaan fisik anak mereka apakah semakin kurus atau bertambah gemuk, maka orangtua dapat menggunakan fasilitas video call atau sejenisnya melalui internet. Walaupun begitu banyak alat komunikasi yang dapat digunakan untuk tetap menjalin komunikasi antara anak dan orang tua yang terpisah jauh, tidak dapat dipungkiri juga banyak anak yang tinggal terpisah dengan orang tua mereka tidak mengungkapkan semua masalah yang mereka hadapi selama tinggal terpisah dengan orang tua.

Fenomena kuliah di luar kota juga terjadi di Universitas Malikussaleh berdasarkan data Biro Akademik Kemahasiswaan, Perencanaan, dan Sistem Informasi (BAAKPSI)jumlah mahasiswa perantauan / luar daerah Aceh pada tahun 2014 di Fakultas Teknik Sipil, Teknik Mesin, Teknik Industri, Teknik Kimia, Teknik Elektro, Teknik Arsitek, dan Teknik Informatika keseluruhan berjumlah 182 orang, Fakultas Ekonomi, Manajemen, Akuntansi, dan Ekonomi Pembangunan jumlah mahasiswa/i yang berasal dari luar daerah Aceh keseluruhan berjumlah 70 orang, Fakultas Hukum 43 orang, Fakultas Kedokteran 26 orang, Fakultas Pertanian, Agroekoteknologi, Agribisnis 77 orang, Fakultas Budidaya Perairan 11 orang dan Fakultas Ilmu Sosial dan Politik, 68 orang.

Berdasarkan observasi awal penulis (14-15 Oktober 2017) mahasiswa perantauan saat berkuliah di Universitas Malikussaleh tidak serta merta putus komunikasi dengan orang tuanya seperti ungkapan Andika Pratama (21) bahwa berkomunikasi dengan orang tuanya lumanyan sering yaitu seminggu 3 kali, tidak hanya orang tuanya yang menelpon terkadang andika juga menelepon orang tuanya jika ada waktu luang atau tidak lagi sibuk dengan jadwal kuliah. Dalam hal ini Andika Selaku mahasiswa Ilmu komunikasi konsentrasi Jurnalistik ini tetap menjaga komunikasi yang baik dalam hubungan keluarganya. 
Tetapi permasalahan komunikasi jarak jauh antara orang tua dengan anak ini tidak semua berjalan lancar seperti yang di ungkapkan oleh Rahman Azhari (22) ia mengatakan bahwa Azhar melakukan komunikasi melalui media telepon dengan orang tuanya bisa di bilang sangat jarang yaitu sebulan sekali, alasannya saat di wawancara karena ia terlalu sibuk dengan jadwal kuliah dan main game dengan teman temannya. Ia hanya menelepon orang tua nya jika kehabisan uang. Azhar mempunyai sifat yang tidak terlalu patuh dengan orang tua nya, disaat orang tuanya bilang dan memberi nasehat kepadanya, ia hanya mengatakan iya padahal hal itu belum tentu dilakukannya dengan maksud agar orang tua nya percaya dengan Azhar dan tidak terlalu khawatir dengan keadaan Azhar saat jauh dari orang tua.

Wida Irma (21) ia mengatakan bahwa berkomunikasi dengan orang tuanya tidak terlalu sering bisa di bilang seminggu sekali paling kurang. Ia akan menelepon orang tuanya jika rindu dengan keluarga, jika butuh sesuatu seperti kehabisan uang dan ngobrol seperti biasanya.Oleh karena itu tidak semua komunikasi jarak jauh yang dilakukan antara anak dengan orang tua berjalan dengan baik.

\section{Rumusan Masalah}

Masalah penelitian ini dibatasi pada proses komunikasi antara orang tua dan anak dengan mahasiswa perantau di Kota Lhokseumawe

\section{Landasan Teori \\ Komunikasi Keluarga}

Komunikasi adalah suatu kegiatan yang pasti dalam kehidupan keluarga. Menurut Soelaeman (Djamarah 2004:16) keluarga adalah sekumpulan orang yang hidup bersama dalam tempat tinggal bersama dan masing - masing anggota keluarga saling mempengaruhi, saling memperhatikan, dan saling menyerah diri. Interaksi sosial yang berlangsung dalam keluarga tidak terjadi dengan sendirinya, tetapi karena ada tujuan atau kebutuhan bersama antara ibu, ayah, dan anak.

Adanya tujuan tertentu yang ingin dicapai atau kebutuhan yang berbeda menyebabkan mereka saling berhubungan dan berinteraksi. Keinginan untuk berhubungan dan berinteraksi tidak terlepas dari kegiatan komunikasi antara orang tua dan anak. Tanpa komunikasi, sepilah kehidupan keluarga terasa hilang, karena di dalamnya tidak ada kegiatan berbicara, berdialog, bertukar pikiran, dan sebagainya, sehingga kerawanan hubungan antara orang tua dan anak sukar untuk dihindari. Oleh karena itu, komunikasi merupakan sesuatu yang essensial dalam kehidupan keluarga. 
Komunikasi yang berlangsung dalam keluarga tidak seperti di pasar. Masyarakat yang melakukan traksaksi jual-beli di pasar dengan tujuan masing-masing. Mereka melakukan perubahan sama sekali terhadap sikap dan perilaku masing-masing. Karena memang bukan itu tujuan mereka. Antara penjual dan pembeli memiliki kebutuhan yang berbeda. Penjual membutuhkan uang, dan pembeli mungkin membutuhkan sandang pangan. Karenanya, komunikasi mereka tidak bernilai pendidikan. Lain halnya dengan komunikasi dalam keluarga. Karena tanggung jawab orang tua adalah mendidik anak, maka komunikasi yang berlangsung dalam keluarga bernilai pendidikan (Djamarah 2004 : 37).

Oleh karna itu komunikasi dalam keluarga dapat berlangsung secara vertikal maupun horizontal (Djamarah 2004:4). Dari dua jenis komunikasi ini berlangsung secara silih berganti komunikasi komunikasi antara suami dan istri, komunikasi antara ayah, ibu dan anak, komunikasi antara ayah dan anak, komunikasi antara ibu dan anak, dan komunikasi antara anak dan anak. Dalam rangka mengakrabkan hubungan keluarga, komunikasi yang harmonis perlu dibangun secara timbal balik dan silih berganti antara orang tua dan anak dalam keluarga.

\section{Komunikasi Orang Tua dan Anak dalam Keluarga}

Orang tua dan anak adalah satu ikatan dalam jiwa. Dalam keterpisahan raga, jiwa mereka bersatu dalam ikatan keabadian. Tak seorang pun dapat mencerai-beraikannya. Ikatan itu dalam bentuk hubungan emosional antara anak dan orang tua yang tercermin dala perilaku. Meskipun suatu saat misalnya, ayah dan ibu mereka sudah bercerai karena suatu sebab, tetapi hubungan emosional antara orang tua dan anak tidak pernah terputus. Sejahat-jahat ayah adalah tetap orang tua yang harus dihormati. Lebih - lebih lagi terhadap ibu yang telah melahirkan dan membesarkan. Bahkan dalam perbedaan keyakinan agama sekalipun antara orang tua dan anak, maka seorang anak tetap diwajibkan menghormati orang tua sampai kapanpun (Djamarah 2004 : 27).

Setiap orang tua yang memiliki anak selalu ingin memelihara, membesarkan, dan mendidiknya. Seorang ibu yang melahirkan anak tanpa ayah pun memiliki naluri untuk memelihara, membesarkan, dan mendidiknya, meski terkadang harus menanggung beban malu yang berkepanjangan. Sebab kehormatan keluarga salah satunya juga ditentukan oleh bagaimana sikap dan perilaku anak dalam menjaga nama baik keluarga dipertaruhkan.

Orang tua dan anak dalam suatu keluarga memiliki kedudukan yang berbeda. Dalam pandangan orang tua, anak adalah buah hati dan 
tumpuan di masa depan yang harus dipelihara dan dididik. Memeliharanya dari segala marabahaya dan mendidiknya agar menjadi anak yang cerdas (Djamarah 2004 : 28).

\section{Metode Penelitian}

Dalam melakukan penelitian ini untuk memperoleh data dan informasi yang akurat makapenulis harus menentukan metode yang akan dilakukan. Adapun metode yang digunakan dalam penelitian ini adalah metode pendekatan kualitatif yang bersifat deskriptif. Dengan maksud penulis lebih tertuju pada permasalahan yang berhubungan dengan komunikasi keluarga dengan studi kasus komunikasi jarak jauh terhadap mahasiswa/i kepada orangtuanya di Universitas Malikussaleh. Penelitian ini berusaha memaparkan fenomena-fenomena yang ada serta berusaha menggambarkan objek dan subjek yang diteliti sesuai dengan apa yang ada, dengan tujuan menggambarkan secara sistematis, fakta dan karakteristik objek yang diteliti secara tepat. Informan penelitian dipilih secara purposive sampling dengan rincian sebagai berikut:

Tabel 1: Informan Mahasiswa yang berhubungan jarak jauh dengan orang tua 1

\begin{tabular}{|l|l|l|l|}
\hline No & Nama Mahasiswa/i & \multicolumn{1}{|c|}{ Usia } & \multicolumn{1}{c|}{ Asal Daerah } \\
\hline 1. & Alfan Darmawan & 22 tahun & Riau \\
\hline 2. & Andika Pratama & 21 tahun & Medan \\
\hline 3. & Antika Widiana & 21 tahun & Aceh Timur \\
\hline 4. & Aulia Khairita & 21 tahun & Kuala Simpang \\
\hline 5. & Ivif Monica & 22 tahun & Padang \\
\hline 6. & Maulidna & 21 tahun & Aceh Singkil \\
\hline 7. & Rahman Azhari & 22 tahun & Padang Sidimpuan \\
\hline 8. & Rahmi Daniati & 21 tahun & Padang \\
\hline 9. & Wida Irma & 21 tahun & Aceh Barat Daya \\
\hline 10. & Winda Sari & 22 tahun & Aceh Tamiang \\
\hline
\end{tabular}

\section{Hasil Penelitian dan Pembahasan Deskripsi Informan}

Pada tahun 2014 ada sekitar 3325 mahasiswa yang masuk di berbagai jurusan yang ada di Universitas Malikussaleh (data BAAKPSI Unimal). Pada penelitian ini hanya mengambil 10 dari 143 orang mahasiswa Ilmu Komunikasi angkatan 2014. Berikut profil singkat dari 10 mahasiswa yang akan dijadikan objek dalam penelitian ini :

1. Andika Pratama 
Andika Pratama lahir di Medan, 24 Juni 1996 dari keluarga Bapak Agus Ampriadi dan Ibu Supyati Hasnah. Andika anak pertama dari 3 orang bersaudara dan memiliki hoby videografi. Andika pratama merupakan mahasiswa jurusan Ilmu Komunikasi konsentrasi Jurnalistik yang berasal dari Sumatera Utara.

2. Antika Widiana

Andika Widiana lahir di Julok, 06 Januari 1997 dari keluarga Bapak Parno dan Ibu Tarmi. Antika anak ke 2 dari 3 bersaudara dan memiliki hobi menonton juga membaca. Antika merupakan mahasiswa jurusan Ilmu Komunikasi konsentrasi Public Relation A yang berasal dari Julok, Aceh Timur.

3. Aulia Khairita (21 tahun)

Aulia Khairita lahir di Kualasimpang 06 November 1996 dari keluarga Bapak Khaidir dan Ibu Cut Safrita. Aulia anak pertama dari 3 bersaudara dan memiliki hobi Fotography. Aulia merupakan mahasiswa jurusan Ilmu Komunikasi konsentrasi Manajemen Komunikasi yang berasal dari Kualasimpang, Aceh Tamiang.

4. Maulidna

Maulidna lahir di Selok Aceh, 02 Agustus 1996 dari keluarga Bapak Sabri dan Ibu Rusni. Maulidna Anak ke 2 dari 4 bersaudara dan memiliki hobi jalan - jalan juga membaca Al-Quran. Lidna merupakan mahasiswa jurusan Ilmu Komunikasi konsentrasi Jurnalistik yang berasal dari Aceh Singkil.

5. Wida Irma

Wida Irma lahir di As. Pinang 04 Juli 1997 dari keluarga Alm. Bapak Zuliqbal dan Ibu Nur Laili. Wida anak ke 3 dari 3 bersaudara dan memiliki hobi jalan - jalan juga olahraga (renang). Wida merupakan mahasiswa jurusan Ilmu Komunikasi konsentrasi yang berasal dari Aceh Barat Daya.

6. Alfan Darmawan

Alfan Darmawan lahir di Lhokseumawe 21 Agustus 1996 dari keluarga Ruslan Ramli dan Ibu Sari Asrini. Alfan anak ke 3 dari 4 bersaudara dan memeiliki hobi membaca juga bermain game. Alfan merupakan mahasiswa jurusan Ilmu Komunikasi konsentrasi Public Relation yang berasal dari Riau.

7. Ivif Monica

Ivif Monica lahir di Padang Ganting, 21 April 1996 dari keluarga Bapak Muslim Sumin dan Ibu Wasrida. Ivif anak pertama dari 3 besaudara dan memiliki hobi memasak juga produksi film. Ivif merupakan mahasiswa jurusan Ilmu Komunikasi konsentrasi Public Relation yang berasal dari Padang, Sumatera Barat. 


\section{Rahmi Daniati (21 tahun)}

Rahmi Daniati lahir di Bukit Tinggi 04 Mei 1996 dari keluarga Bapak Darmis dan Ibu Yusnida. Rahmi anak pertama dari 2 bersaudara dan memiliki hobi membaca. Rahmi merupakan mahasiswa jurusan Ilmu Komunikasi konsentrasi Public Relation A yang berasal dari Padang.

9. Winda Sari (22 tahun)

Winda Sari lahir di Kualasimpang 01 Desember 1996 dari keluarga Bapak Bahrumsyah Putra dan Ibu Misniar. Winda anak pertama dari 4 bersaudara dan memiliki hobi nonton dan bermain game. Winda merupakan mahasiswa jurusan Ilmu Komunikasi konsentrasi Public Relation B yang berasal dari Kualasimpang, Aceh Tamiang.

10. Rahman Azhari (22 tahun)

Rahman Azhari lahir di Padangsidimpuan 22 Desember 1995 dari keluarga Bapak Azhar Harahap SE, dan Ibu Rahmadani Nasution S.Pd. Rahman anak kedua dari 4 bersaudara dan memiliki hobi jalan - jalan juga bermain game. Rahman merupakan mahasiswa jurusan Ilmu Komunikasi konsentrasi Public Relation B yang berasal dari Padangsidimpuan, Sumatera Utara.

Tabel 4.1 Informan Mahasiswa yang berhubungan jarak jauh dengan orang tua.

\begin{tabular}{|l|l|l|l|}
\hline No & Nama Mahasiswa/i & \multicolumn{1}{|c|}{ Usia } & \multicolumn{1}{c|}{ Asal Daerah } \\
\hline 1. & Alfan Darmawan & 22 tahun & Riau \\
\hline 2. & Andika Pratama & 21 tahun & Medan \\
\hline 3. & Antika Widiana & 21 tahun & Aceh Timur \\
\hline 4. & Aulia Khairita & 21 tahun & Kuala Simpang \\
\hline 5. & Ivif Monica & 22 tahun & Padang \\
\hline 6. & Maulidna & 21 tahun & Aceh Singkil \\
\hline 7. & Rahman Azhari & 22 tahun & Padang Sidimpuan \\
\hline 8. & Rahmi Daniati & 21 tahun & Padang \\
\hline 9. & Wida Irma & 21 tahun & Aceh Barat Daya \\
\hline 10. & Winda Sari & 22 tahun & Aceh Tamiang \\
\hline
\end{tabular}

Komunikasi keluarga jarak jauh dalam penelitian ini merujuk pada teori Skema Hubungan Keluarga yang dikemukakan oleh Mary Anne Fitzpatrick ia mengatakan bahwa teori skema hubungan keluarga pada umumnya terjadi atas pengetahuan mengenai diri sendiri, diri orang lain, hubungan yang sudah dikenal dan juga pengetahuan yang mengenai bagaimana cara berinteraksi dalam suatu hubungan. Pengetahuan ini memberikan image atau gambaran terhadap suatu hubungan berdasarkan pengalaman sendiri dan memandu perilaku dalam menjalani hubungan itu 
(Morissan 2010 : 159). Terdapat dua orentasi penting dalam skema hubungan keluarga, yaitu orientasi percakapan dan orientasi kepatuhan. Kedua orientasi ini merupakan variabel, sehingga masing - masing keluarga memiliki tingkat atau derajat berbeda dalam hal seberapa banyak orientasi percakapan dan kepatuhan yang dimilikinya. Kedua orientasi tersebut memiliki karakteristik sebagai berikut :

- Orientasi Percakapan

Orientasi percakapan yang dimaksud dalam penelitian ini adalah peneliti ingin mengetahui tingkat percakapan tinggi atau rendahnya komunikasi keluarga antara orang tua dan anak.

- Orientasi kepatuhan

Orientasi kepatuhan yang dimaksud dalam penelitian ini adalah peneliti ingin mengetahui tingkat kepatuhan anak terhadap orang tua ketika tinggal berjauhan.

Berikut gambar skema hubungan yang terjadi dalam keluarga .

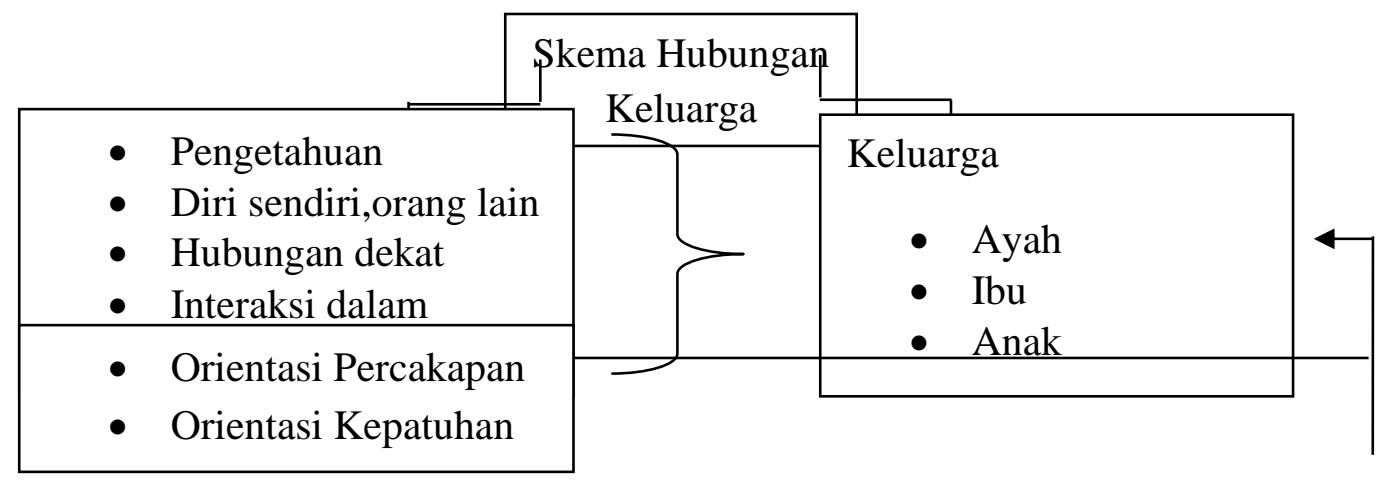

Gambar 4.1 Skema hubungan keluarga

Dalam penelitian ini peneliti memilih 10 orang yang akan dijadikan informan dalam penelitian yang berhubungan dengan komunikasi keluarga dalam hubungan jarak jauh. Berikut nama - nama informan yang berhubungan jarak jauh dengan orangtuanya :

1. Andika Pratama (21 tahun)

Andika pratama merupakan mahasiswa jurusan Ilmu Komunikasi konsentrasi Jurnalistik yang berasal dari Sumatera Utara.

a. Orientasi Percakapan

Dalam hal ini peneliti ingin mengetahui seberapa banyak orang tua dan anak melakukan komunikasi dalam hubungan jarak jauh.

Ketika peneliti menanyakan apakah Andika melakukan komunikasi dengan orang tuanya? dan dengan menggunakan media apa mereka melakukan komunikasi jarak jauh ? 
"Kalau masalah komunikasi ya tentu saya melakukan komunikasi dengan orang tua saya, menggunakan telepon genggam seperti nelpon dan sms juga melalui media sosial seperti video call dan chatting".

Pertanyaan selanjutnya mengenai seberapa sering anda melakukan komunikasi dengan orang tua anda ? dan topik apa yang biasa di bicarakan dengan orang tua ?

"Tidak tentu ya kadang 3 hari sekali kadang seminggu bisa beberapa kali. Hal yang kami bicarakan itu tiap kali nelpon atau perminggu, ya sekedar saling bertanya kabar, bertanya tentang kesehatan masing-masing enggak ada yang lain-lain sih".

Pertanyaan selanjutnya mengenai berapa lama durasi percakapan Andika dengan orang tua ketika berkomunikasi jarak jauh ? dan apakah ada hambatan ketika berkomunikasi jarak jauh, jika ada apa saja yang menjadi faktor penghambat komunikasi jarak jauh ?

"Durasi percakapan itu kalau telfon dari ponsel 5-10 menit tapi kalau dari media chatting bisa lama lah seperti itu. Kemudian masalah hambatan itu ada sih seperti tidak adanya pulsa, paket internet, dan sinyal karena rumah saya di pedalaman gitu jadi agak susah sinyal”. (Wawancara 28 Mei 2018).

Berikut adalah rincian daftar panggilan Andika dengan orang tua ketika berkomunikasi jarak jauh :

Pada tanggal 22 Mei 2018, 16 panggilan tak terjawab dari orang tua Andika. Pada tanggal 03 Juni, 6 panggilan tak terjawab dari orang tua Andika, kemudian orangtua menelpon Andika dengan durasi 27 detik. Pada tanggal 04 Juni, 4 panggilan tak terjawab dari orang tua Andika. Pada tanggal 06 Juni, orang tua menghubungi Andika membahas tentang kesehatan Andika dengan durasi 1 menit 18 detik. Pada tanggal 09 Juni, 7 panggilan tak terjawab dari orangtuaAndika. Pada tanggal 11 Juni, 1 panggilan tak terjawab dari orang tuaAndika. Pada tanggal 13 Juni, orang tua menelpon membahas tentang masalah ekonomi Andika saat di perantauan.

b. Orientasi Kepatuhan

Kemudian peneliti menanyakan apakah antara Andika dengan orang tua ada kesepakatan/aturan ketika berhubungan jarak jauh, jika ada aturan seperti apa yang anda sepakati dengan orang tua ? 
"Saya dengan orang tua itu tidak ada aturan atau kesepakatan yang diberikan kepada saya namun, adanya larangan yang tidak baik hal-hal yang tidak baik di anjurkan untuk menghindari yang namanya rokok itu saja sih".

Pertanyaan selanjutnya mengenai apakah Andika pernah melanggar nasehat atau aturan yang diberikan oleh orang tua ketika berhubungan jarak jauh?

"Oh tidak ada, belum pernah dan saya menerima nasihat yang diberikan oleh orang tua saya". (Wawancara 28 Mei 2018).

Analisis :

Dari jawaban informan pertama selama di wawancarai dapat diketahui bahwa informan sangat menjaga komunikasi dengan orang tua disaat tinggal berjauhan dengan orang tuanya, meskipun terkadang selalu orang tua yang menelpon Andika duluan. Media yang digunakan informan dalam berkomunikasi yaitu handphone, seperti telepon dan sms, serta aplikasi socialmessenger seperti chatting. Kemudian pada wawancara informan yang pertama ia menjelaskan bahwa ia juga sering melakukan komunikasi dengan orang tuanya yakni seminggu bisa berkali - kali. Hal yang dibicarakan informan dengan orang tuanya adalah tentang kabar informan, tentang keadaan masing - masing, kemudian membahas tentang ekonomi dan membeli keperluan informan selama di perantauan.

Namun berkomunikasi jarak jauh tidak luput dari yang namanya hambatan, adanya faktor hambatan seperti tidak adanya pulsa, paket internet, juga sinyal yang membuat komunikasi tidak selalu berjalan dengan lancar dikarenakan informan ini tinggal jauh dari kota. Pada infoman yang pertama ini tidak adanya aturan yang diberikan oleh orang tuanya namun sedikit nasehat agar menjauhi hal-hal yang tidak baik yang nantinya akan merugikan diri sendiri, ini menunjukkan bahwa informan sangat patuh serta menghargai apa yang telah diberikan oleh orang tuanya.

2. Antika Widiana (21 tahun)

Antika merupakan mahasiswa jurusan Ilmu Komunikasi konsentrasi Public Relation A yang berasal dari Julok, Aceh Timur.

a. Orientasi Percakapan

Dalam hal ini peneliti ingin mengetahui seberapa banyak orang tua dan anak melakukan komunikasi dalam hubungan jarak jauh.

Setelah peneliti selesai mewawancarai informan pertama, peneliti melanjutkan wawancara ke informan kedua. Informan kedua ini jarang sekali pulang ke kampung halamannya. Saat diwawancarai peneliti menanyakan apakah Antika melakukan komunikasi dengan orang tuanya? 
dan dengan menggunakan media apa mereka melakukan komunikasi jarak jauh?

"Kalau ditanya masalah komunikasi ya setiap mahasisiwa adalah telpon dengan orang tuanya kan, kalau berkomunikasi dengan orangtua itu melalui telepon genggam seperti nelpon dan sms".

Pertanyaan selanjutnya mengenai seberapa sering antika melakukan komunikasi dengan orang tua ? dan topik apa yang biasa di bicarakan dengan orang tua?

"Kalo saya sama orang tua itu biasanya nelpon seminggu sekali karena lagi sibuk-sibuknya sama nyusun skripsi. Dan yang biasa kami bicarakan itu memang tentang kabar masing-masing, tentang kuliah saya, bahkan ini di bulan ramadhan kemarin ibu ada nelpon nanyak makan pakek apa udah sahur belum ya seperti itu lah, terus kemarin ibu ada nelpon kasi tahu kalau tetangga ada yang meninggal gitu, ya tidak banyak sih itu saja".

Pertanyaan selanjutnya mengenai berapa lama durasi percakapan Antika dengan orang tua ketika berkomunikasi jarak jauh ? apakah ada hambatan ketika berkomunikasi jarak jauh, jika ada apa saja yang menjadi faktor penghambat komunikasi jarak jauh?

"Jadi paling lama durasinya sekitaran 2-3 menit lah. Mengenai adanya hambatan kalau saya pribadi pulsa lah ya karna anak kos biasa itu terus sama baterai hape saya cepat kali habis ...”. (Wawancara 28 Mei 2018).

Berikut adalah rincian daftar panggilan informan dengan orang tua ketika berkomunikasi jarak jauh :

Pada tanggal 14 Mei 2018, Antika sedang dalam perjalanan dari rumah menuju ke lhokseumawe di tempat kosan Antika satu panggilan tak terjawab dari orang tua Antika, kemudian Antika menelpon orang tuanya untuk memberi tahu bahwa Antika sedang dalam perjalanan dengan durasi bicara 1 menit. Pada tanggal 20 Mei, Antika menelpon orang tuanya agar orang tuanya menghubungi kembali karena Antika tidak ada pulsa, dengan durasi bicara 10 detik, kemudian orang tua menelpon Antika untuk memberi tau bahwa orang tuanya pun sedang tidak adanya pulsa untuk menelpon dengan durasi bicara 20 detik. Tanggal 22 Mei, Antika menelpon orang tuanya sebanyak 3 kali terbatasnya sinyal sehingga komunikasi tidak berjalan dengan lancar dan membuat Antika menelpon 
sampai berkali- kali dengan durasi 10 detik, 10 detik dan 9 detik. Pada tanggal 05 Juni, Antika menelpon orang tuanya sebanyak empat kali membahas hanya sekedar basa - basi saja dengan durasi 44 detik, 32 detik, 21 detik dan 39 detik. Tanggal 17 Juni, satu panggilan tak terjawab dari orang tua Antika.

b. Orientasi Kepatuhan

Sama dengan informan pertama peneliti menanyakan apakah antara Antika dengan orang tua ada kesepakatan/aturan ketika berhubungan jarak jauh, jika ada aturan seperti apa yang anda sepakati dengan orang tua?

"Aturan atau kesepakatan itu seperti nya tidak ada karena orang tua saya sudah percaya sama saya maka dari itu saya harus menjaga kepercayaan yang telah diberikan orang tua kepada saya".

Pertanyaan selanjutnya apakah anda pernah melanggar nasehat atau aturan yang diberikan oleh orang tua anda ketika berhubungan jarak jauh?

"Sepertinya tidak ada ya, saya belum pernah melanggar peraturan yang diberikan oleh orang tua saya". (Wawancara 28 Mei 2018). Analisis :

Dari jawaban Antika kedua dapat diketahui bahwa informan kedua ini melakukan komunikasi jarak jauh dengan orang tuanya walau ia sedang sibuk-sibuknya menyusun skripsi tugas akhir ia menyempatkan untuk memberi kabar seminggu sekali kepada orang tuanya. Media yang digunakan informan kedua itu adalah handphone seperti telpon dan sms. Topik yang dibahas setiap minggu berkomunikasi adalah tentang kabar masing - masing, tentang perkuliahan Antika, tentang makan sehari - hari, masalah ekonomi Antika saat diperantauan serta keduanya juga menelpon jika ada hal penting yang ingin disampaikan.

Masalah hambatan yang terjadi pada saat berkomunikasi sama halnya dengan informan pertama yaitu tidak jarang adanya pulsa yang membuat Antika jarang menghubungi keluarganya, serta baterai handphone yang mulai rusak menjadi hambatan informan kedua dalam berkomunikasi dengan orang tuanya. Kemudian mengenai aturan pada informan kedua tidak ada aturan tertentu karena orang tuanya sudah menaruh kepercayaan kepada Antika untuk dijaga kepercayaan yang diberikan sebaik-baiknya, menunjukkan bahwa informan kedua patuh pada nasehat yang diberikan oleh orang tuanya.

3. Aulia Khairita (21 tahun)

Aulia merupakan mahasiswa jurusan Ilmu Komunikasi konsentrasi Manajemen Komunikasi yang berasal dari Kualasimpang, Aceh Tamiang. 
a. Orentasi Percakapan

Dalam hal ini peneliti ingin mengetahui seberapa banyak orang tua dan anak melakukan komunikasi dalam hubungan jarak jauh.

Setelah mewawancarai informan kedua peneliti melanjutkan wawancara ketiga. Saat diwawancarai mengenai apakah Aulia melakukan komunikasi dengan orang tua ? media apa yang di gunakan dalam berkomunikasi?

"Saya melakukan komunikasi dengan orang tua, pakai hadphone dan aplikasi whatsapp, seperti nelpon sms juga chatting".

Pertanyaan selanjutnya mengenai seberapa sering Aulia melakukan komunikasi dengan orang tua ? topik apa yang biasa di bicarakan dengan orang tua?

"Tetapi saya jarang sekali jadi dalam sebulan bisa 2 atau 3 kali, biasanya berkomunikasi pun kalau ada perlunya saja, dan yang menjadi topik pembicaraan itu tidak banyak sih kalau misalkan saya butuh apa-apa atau kehabisan uang bulanan gitu saya telepon, juga dari pihak orang tua saya kalau ada sesuatu yang penting yang mendesak ya dikasi tau, tidak banyak sih memang jarang telepon".

Pertanyaan selanjutnya mengenai berapa lama durasi percakapan Aulia dengan orang tua ketika berkomunikasi jarak jauh ? apakah ada hambatan ketika berkomunikasi jarak jauh, jika ada apa saja yang menjadi faktor penghambat komunikasi jarak jauh?

"Durasinya itu tidak lama-lama kira - kira 2 menit lah.

Masalah hambatan tidak ada hambatan sama sekali karena memang jarang berkomunikasi ...". (Wawancara 31 Mei 2018).

Berikut adalah rincian daftar panggilan informan dengan orang tua ketika berkomunikasi jarak jauh :

Pada tanggal 17 Mei 2018, Aulia di telpon oleh orang tuanya sebanyak 2 kali untuk menanyakan tentang bagaimana keadaan Aulia di rumah saudaranya dengan durasi 2 menit 43 detik. Pada tanggal 03 Juni, Aulia menelpon orang tuanya untuk membahas masalah ekonomi Aulia yang sudah mulai habis dengan durasi 1 menit.

b. Orientasi Kepatuhan

Setelah menanyakan tentang bagaimana komunikasi yang terjadi dalam keluarga informan ketika dalam jarak jauh peneliti menanyakan apakah antara Aulia dengan orang tua ada kesepakatan/aturan ketika 
berhubungan jarak jauh, jika ada aturan seperti apa yang disepakati dengan orang tua ?

"Masalah aturan tidak ada sih karena disini saya tinggal di rumah saudara jadi orang tua sudah percaya sama saya ya jaga diri saja sebaik-baik nya".

Pertanyaan selanjutnya apakah pernah melanggar nasehat atau aturan yang diberikan oleh orang tua ketika berhubungan jarak jauh ? Analisis :

"Sepertinya belum pernah". (Wawancara 31 Mei 2018).

Dalam wawancara pada informan ketiga ini dapat diketahui bahwa Aulia jarang melakukan komunikasi dengan orang tuanya. Media yang digunakan handphone dan aplikasi whatsapp seperti menelepon. Topik yang dibahas pun tidak banyak dikarenakan informan ketiga ini sebulan 3 kali melakukan ko munikasi jarak jauh dengan durasi 2 menit, tentang bagaimana keadaan informan di rumah saudaranya, saling bertanya kabar masing-masing serta masalah ekonomi untuk kebutuhan informan di saat tinggal diperantauan.

Mengenai hambatan pada informan ketiga ini tidak adanya hambatan di karenakan Aulia dengan orang tuanya jarang sekali melakukan komunikasi jarak jauh dan tidak ada aturan tertentu pada Aulia karena orang tua Aulia sudah percaya untuk dijaga sebaik-baiknya, menunjukkan bahwa informan ketiga walaupun jarang melakukan komunikasi dengan orang tuanya tetapi sangat menghargai nasehat yang diberikan oleh orang tuanya.

4. Maulidna (21 tahun)

Lidna merupakan mahasiswa jurusan Ilmu Komunikasi konsentrasi Jurnalistik yang berasal dari Aceh Singkil.

a. Orientasi Percakapan

Dalam hal ini peneliti ingin mengetahui seberapa banyak orang tua dan anak melakukan komunikasi dalam hubungan jarak jauh.

Setelah mewawancarai informan ketiga peneliti melanjutkan wawancara informan keempat yang setahun bisa 2 atau 3 kali pulang kampung dikarenakan kampung halaman informan bisa menempuh jarak 18 jam membuat informan jarang pulang ke kampung halamannya selain jauh juga ongkos untuk pulang tidak murah.

Selanjutnya peneliti menanyakan apakah Maulidna melakukan komunikasi dengan orang tua ? media apa yang digunakan dalam berkomunikasi ? 
"Jika ditanya mengenai komunikasi jarak jauh dari orang tua iya saya melakukan, melalui handphone seperti nelpon, sms juga melalui aplikasi seperti videocall".

Pertanyaan selanjutnya mengenai seberapa sering Lidna melakukan komunikasi dengan orang tua? topik apa yang dibicarakan dengan orang tua?

"Biasanya itu 3 hari sekali terkadang bisa seminggu sekali karena masing-masing sibuk dan yang kami bicarakan tiap minggu ya tentang saling tanya kabar, terus masalah kuliahnya gimana dan yang paling umum masalah dana sering kali gitu kalau masalah uang itu dipertanyakan namun kalau masih ada ya tidak diperpanjang lagi.

Pertanyaan selanjutnya mengenai berapa lama durasi percakapan Lidna dengan orang tua ketika berkomunikasi jarak jauh ? apakah ada hambatan ketika berkomunikasi jarak jauh, jika ada apa saja yang menjadi faktor penghambat komunikasi jarak jauh?

"Durasinya tidak tentu bisa jadi 20 menit bahkan sampai 30 menit karena kalau ngomong itu bukan sama orang tua saja kadang ada sama adik juga. Masalah hambatan sudah pasti ada mungkin sama dengan yang lain lah ya yaitu pulsa kadang ada kadang tdak ada gitu dan sinyal kadang dikosan bagus jaringan nya tapi dikampung tidak bagus jaringannya ...". (Wawancara 30 Mei 2018).

Berikut adalah rincian daftar panggilan informan dengan orang tua ketika berkomunikasi jarak jauh :

Pada tanggal 04 Mei 2018, orang tua menelpon Lidna membahas tentang kabar masing - masing dan bertanya tentang keadaan Lidna di perantauan dengan durasi bicara 18 menit 33 detik. Tanggal 07 Mei, Lidna menelpon orangtuanya membahas tentang masalah ekonomi dengan durasi sekitar 17 menit. Tanggal 10 Mei, Lidna menelpon orantuanya karena rindu dengan durasi bicara 20 menit 44 detik. Tanggal 18 Mei, orang tua menelpon membahas tentang perkuliahan Lidna dengan durasi bicara 22 menit. Kemudian tanggal 17 Juni, orang tua menelpon Lidna menelpon sekedar bertanya kegiatan Lidna di kosan dengan durasi bicara 23 menit.

b. Orientasi Kepatuhan

Setelah menanyakan tentang bagaimana komunikasi yang terjadi dalam keluarga ketika dalam jarak jauh selanjutnya peneliti menanyakan apakah antara Lidna dengan orang tua ada kesepakatan/aturan ketika 
berhubungan jarak jauh, jika ada aturan seperti apa yang disepakati dengan orang tua ?

"Oh kalau kami tidak ada aturan tertentu karena orang tua sudah percaya sama saya jadi saya rasa tidak ada aturan yang harus di taati".

Pertanyaan selanjutnya apakah Lidna pernah melanggar nasehat atau aturan yang diberikan oleh orang tua ketika berhubungan jarak jauh ?

"Saya rasa belum pernah lah ya". (Wawancara 30 Mei 2018). Analisis :

Pada jawaban informan keempat dapat diketahui bahwa Lidna melakukan komunikasi jarak jauh dengan orang tuanya dan komunikasi tersebut berjalan dengan baik karena pada Lidna juga sering melakukan komunikasi dengan durasi bicara yang lumanyan lama yaitu bisa mencapai 30 menit lantaran bukan berbicara dengan ayah ibu saja melainkan dengan adiknya atau sanak saudara lainnya.Topik yang dibicarakan antara keduanya yaitu tentang saling bertanya kabar, bertanya tentang kesehatan masing-masing dan hal pribadi lainnya seta tentang uang bulanan dan keperluan Lidna saat dikosan.

Adanya hambatan susah sinyal dan jarang adanya pulsa yang membuat komunikasi jarak jauh informan keempat ini terganggu. Namun pada informan keempat ini tidak adanya aturan yang diberikan oleh orang tuanya karena orang tuanya sudah percaya kepada Lidna untuk dijaga sebaik-baiknya, ini menunjukkan bahwa Lidna selain menjaga komunikasi jarak jauh dengan keluarganya informan juga patuh atas nasehat yang diberikan oleh orang tuanya.

5. Wida Irma (21 tahun)

Wida merupakan mahasiswa jurusan Ilmu Komunikasi konsentrasi yang berasal dari Aceh Barat Daya.

a. Orientasi Percakapan

Dalam hal ini peneliti ingin mengetahui seberapa banyak orang tua dan anak melakukan komunikasi dalam hubungan jarak jauh.

Setelah mewawancarai informan keempat peneliti melanjutkan wawancara pada informan kelima dan menanyakan apakah Wida melakukan komunikasi dengan orang tua ? media apa yang digunakan dalam berkomunikasi ?

"Namanya saja kita anak rantau pastilah kita berkomunikasi sama orang tua kita, menggunakan media telepon, videocall ya tergantunglah kalau orang tua dan saya tidak sibuk ya video call"'. 
Pertanyaan selanjutnya mengenai seberapa sering Wida melakukan komunikasi dengan orang tua ? topik apa yang dibicarakan dengan orang tua?

"Saya berkomunikasi sama orang tua itu seminggu sekali lah tidak tentu juga. Bahasan kami setiap nelpon itu saling bertanya kabar, tentang perkuliahan, dan kesehatan".

Pertanyaan selanjutnya mengenai berapa lama durasi percakapan Wida dengan orang tua ketika berkomunikasi jarak jauh ? apakah ada hambatan ketika berkomunikasi jarak jauh, jika ada apa saja yang menjadi faktor penghambat komunikasi jarak jauh?

"Dengan durasi bicara itu lama juga sekitar satu jam karena yang dibahas kadang bukan tentang kuliah saja. Masalah hambatan itu pasti ada ya seperti orang tua dan saya kadang tidak ada pulsa cuma itu sih hambatannya ...". (Wawancara 01 Juni 2018).

Berikut adalah rincian daftar panggilan informan dengan orang tua ketika berkomunikasi jarak jauh :

Pada tanggal 03 Juli 2018, Wida ditelpon oleh orang tuanya dengan durasi 2 menit membahas tentang kabar masing - masing. Kemudian pada tanggal 05 Juli, Wida kembali ditelpon oleh orang tuanya dengan durasi bicara 7 menit mereka membahas tentang kondisi masing masing apakah sehat dan makanan apa sehari - hari. Tanggal 08 Juli, orang tua Wida menelpon informan sekedar basa basi karena terbatasnya pulsa orang tua dengan durasi bicara selama 19 detik. Wida menelpon keluarganya atau orang tuanya dengan durasi bicara 10 detik pada jam 13.32 Wida menelpon karena kehabisan pulsa dan meminta orang tuanya untuk mengisi pulsa, setelah pulsa masuk Wida menghubungi keluarganya pada jam 13.55 untuk mengatakan bahwa pulsa sudah masuk dengan durasi 13 detik. Tanggal 11 Juli, Wida di telpon oleh orang tuanya membahas tentang perkuliahan Wida yang sedang menyusun skripsi dengan durasi bicara selam 21 menit. Tanggal 12 Juli, Wida melakukan panggilan keluar kemudian orang tuanya menelpon sebanyak tiga kali dengan durasi 3 detik, 13 detik dan 34 detik lantaran sinyal kurang bagus maka telepon terputus.Kemudian minggu selanjutnya orangtua kembali menelpon untuk menanyakan ekonomi Wida saat di perantauan dengan durasi selama 9 menit.

b. Orientasi Kepatuhan 
Selanjutnya peneliti menanyakan apakah antara Wida dengan orang tua ada kesepakatan/aturan ketika berhubungan jarak jauh, jika ada aturan seperti apa yang disepakati dengan orang tua ?

“... Aturan ada ya kita anak kos sama di kampung itu beda penilaian, kalau dari segi kesehatan disuruh makan yang teratur, tapi kalo dari segi yang lain mungkin itu jalan-jalan ya, setiap hari minggu orang tua itu selalu nelpon karena tau anaknya pasti keluar jalan-jalan, tidak dibolehkan keluar jalan-jalan sama orang tua saya".

Pertanyaan selanjutnya mengenai apakah Wida pernah melanggar nasehat atau aturan yang diberikan oleh orang tua ketika berhubungan jarak jauh?

"Pernah, seperti tidak boleh keluar jalan - jalan, tetapi saya keluar juga, kalau tidak keluar tidak enak kan karena sudah di ajak sama temen jadi saya bilang dulu baik-baik sama orang tua bagaimana biar orang tua tidak khawatir sama saya". (Wawancara 01 Juni 2018).

\section{Komunikasi Keluarga Dalam Hubungan Jarak Jauh}

Komunikasi adalah suatu kegiatan yang pasti dalam kehidupan keluarga. Menurut Soelaeman (Djamarah 2004:16) keluarga adalah sekumpulan orang yang hidup bersama dalam tempat tinggal bersama dan masing - masing anggota keluarga saling mempengaruhi, saling memperhatikan, dan saling menyerah diri. Interaksi sosial yang berlangsung dalam keluarga tidak terjadi dengan sendirinya, tetapi karena ada tujuan atau kebutuhan bersama antara ibu, ayah, dan anak.

Keluarga merupakan konsep yang multidimensi. Para ilmuwan sosial bersilang pendapat mengenai rumusan definisi keluarga yang bersifat universal. Salah satu ilmuwan yang permulaan mengkaji keluarga adalah George Murdock. Dalam bukunya Social Structure, Murdock menguraikan bahwa keluarga merupakan kelompok sosial yang memiliki karakteristik tinggal bersama, terdapat kerja sama ekonomi, dan terjadi proses reproduksi (Lestari 2012:3).

Adanya tujuan tertentu yang ingin dicapai atau kebutuhan yang berbeda menyebabkan mereka saling berhubungan dan berinteraksi. Keinginan untuk berhubungan dan berinteraksi tidak terlepas dari kegiatan komunikasi antara orang tua dan anak. Tanpa komunikasi, sepilah kehidupan keluarga terasa hilang, karena di dalamnya tidak ada kegiatan berbicara, berdialog, bertukar pikiran, dan sebagainya, sehingga kerawanan hubungan antara orang tua dan anak sukar untuk dihindari. 
Oleh karena itu, komunikasi merupakan sesuatu yang essensial dalam kehidupan keluarga.

Pada penelitian ini komunikasi keluarga dalam hubungan jarak jauh antara mahasiswa dan orang tuanya berjalan dengan baik, mereka menjaga komunikasi dengan orangtuanya meski dalam jarak yang berjauhan. Intensitas komunikasi yang dilakukan oleh mahasiswa dengan orang tuanya rata-rata sekitar 1 jam paling lama dan 3 menit paling sedikit.

Topik yang dibicarakan setiap kali melakukan komunikasi ialah tentang masalah ekonomi yang menjadi hal utama untuk dibahas, kemudian masalah kesehatan saling bertanya kabar keadaan masingmasing, masalah perkuliahan serta masalah keadaan mahasiswa seperti apa ketika berada diperantauan. Namun pada hasil wawancara yang dilakukan beberapa bulan yang lalu bahwa tidak semua mahasiswa yang melakukan komunikasi dengan keluarganya menceritakan hal yang dilakukan pada saat di perantauan, ada berbagai alasan yang membuat mereka tidak terbuka juga tidak ingin orang tuanya tau keadaan mereka pada saat diperantauan.

Pada penelitian ini peneliti mengambil informan mahasiswa ilmu komunikasi angkatan 2014 yang berasal dari perantauan yang dimaksud dengan perantauan di dalam penelitian ini adalah mahasiswa yang berasal dari luar daerah kota Lhokseumawe Aceh Utara.

Berdasarkan hasil wawancara kepada informan yang memenuhi kriteria dari peneliti maka yang menjadi faktor penghambat dalam komunikasi jarak jauh adalah yang pertama mahasiswa terlalu sibuk dengan urusan perkuliahan, dengan tugas-tugas kuliah atau organisasi diluar membuat mahasiswa jarang menelpon dan bertanya kabar tentang keadaan orang tua di kampung. Yang kedua adalah terbatasnya jaringan telepon genggam dikarenakan ada beberapa informan yang tempat tinggalnya berada jauh dari kota, sinyal telepon yang kadang ada kadang tidak membuat mereka jarang menelpon, mereka hanya menelpon ketika ada hal yang diperlukan atau ada hal penting yang ingin disampaikan. Yang ketiga pulsa, biaya untuk menelpon yang jarang ada juga menjadi faktor penghambat komunikasi jarak jauh antara mahasiswa dan orang tua. Pada saat wawancara banyak dari mereka mengatakan faktor yang menjadi hambatannya adalah pulsa karenanya tidak jarang mereka menunggu ditelpon oleh orang tuanya lantaran biaya untuk menelpon tidak ada.

Komunikasi yang terjadi diantara informan dengan orang tuanya juga tidak selamanya berjalan dengan baik dan efektif. Hal ini, karena jika dalam suatu hubungan terdapat suatu masalah atau konflik, maka 
komunikasi yang terjadi juga mungkin tidak akan efektif. Sehingga dalam buku Komunikasi Antarpribadi, Alo Liliweri mengutip pendapat Joseph A.Devito mengenai ciri komunikasi antarpribadi yang efektif (jurnal Ginting $2013: 31$ ), yaitu:

\section{A. Keterbukaan (openness)}

Kualitas keterbukaan mengacu pada tiga aspek dari komunikasiinterpersonal. Pertama, komunikator yang efektif harus terbuka kepada komunikannya. Hal ini bukan berarti bahwa orang harus dengan segera membukakan semua riwayat hidupnya. Memang ini mungkin menarik, tetapi biasanya tidak membantu komunikasi. Sebaliknya, harus ada kesediaan untuk membuka diri mengungkapkan informasi yang biasanya disembunyikan, asalkan pengungkapan diri ini patut dan wajar. Aspek kedua mengacu pada kesediaan komunikator untuk bereaksi secara jujur terhadap stimulus yang datang. Orang yang diam, tidak kritis, dan tidak tanggap pada umumnya merupakan komunikan yang menjemukan. Bila ingin komunikan bereaksi terhadap apa yang komunikator ucapkan, komunikator dapat memperlihatkan keterbukaan dengan cara bereaksi secara spontan terhadap orang lain. Aspek ketiga menyangkut kepemilikan perasaan dan pikiran dimana komunikator mengakui bahwa perasaan dan pikiran yang diungkapkannya adalah miliknya dan ia bertanggungjawab atasnya. Keterbukaan mahasiswa dan orangtuanya ini dari sepuluhinforman hanya $50 \%$ yang bisa terbuka. Hal ini karena mahasiswa takut untuk jujur dengan orangtuanya karena takut dilarang dan takut orangtuanya menjadi khawatir. Dari penjelasan diatas dapat disimpulkan bahwa kriteria yang diajukan Joseph De Vito mengenai komunikasi yang efektif tidak terjadi pada hubungan jarak jauh anak dan orangtua.

\section{Penutup}

Komunikasi sudah pasti terjadi dalam keluarga tanpa komunikasi maka hubungan dalam keluarga menjadi sepi dan tidak harmonis. Komunikasi dapat terjadi kapan pun dan dimana saja berada begitu juga dengan komunikasi jarak jauh yaitu komunikasi yang dilakukan tidak secara langsung atau tatap muka melainkan perlu adanya alat media komunikasi dalam berkomunikasi. Hasil dari wawancara peneliti dengan 10 orang informan menunjukkan bahwa mahasiswa melakukan komunikasi dengan orang tuanya ketika berhubungan jarak jauh, dan dalam hal berkomunikasi orang tua terlebih dahulu menghubungi daripada anak yang menghubungi orangtua.Dari hasil wawancara terdapat 50\% informan yang tinggal terpisah dari orangtuanya memilih untuk tidak menceritakan semua hal dan masalah yang dihadapinya. Hal ini karena 
mahasiswa takut membuat orangtuanya menjadi cemas dan khawatir terhadap keadaan anaknya ketika berada diperantauan.

Faktor yang menjadi penghambat dalam komunikasi jarak jauh yaitu sibuknya mahasiswa dengan tugas perkuliahan dan organisai sehingga mereka tidak memiliki banyak waktu untuk melakukan komunikasi dengan orangtuanya. Hal lain yaitu persoalan waktu, terkadang waktu komunikasi tidak tepat yaitu ketika salah satu diantaranya sedang sibuk maka komunikasi yang terjadi pun pun sangat singkat. Hal terakhir yaitu mengenai jaringan telepon genggam (hp) dan pulsa. Jaringan terkadang menganggu aktifitas komunikasi yang terjadi terkadang ditengah perbincangan tiba - tiba terputus karena jaringan hilang. Serta pulsa menjadi penghambat bagi mahasiswa dalam melakukan komunikasi dengan orangtuanya karna di zaman ini mahasiswa lebih mengutamakan membeli paket data dibandingkan dengan membeli pulsa sehingga meraka menunggu orangtua terlebih dahulu untuk menghubunginya.

\section{Daftar Pustaka}

Cangara, Hafied. 2006. Pengantar Ilmu Komunikasi, Jakarta: PT. Raja Grafindo Persada.

Djamarah, Bahri Syaiful. 2004. Pola Komunikasi Orang Tua dan Anak Dalam Keluarga, Jakarta: Renika Cipta.

Ginting, Sabrina Novia. 2013. Komunikasi dalam hubungan jarak jauh. Jurnal USU, Volume 2, No. 6, 16-18. FISIP USU.

Lestari, Sri. 2012. Psikologi Keluarga: Penanaman Nilai dan Penanganan Konflik

dalam Keluarga,Jakarta: Kencana Prenada Media Group

Mulyana, Deddy. 2008. Metodologi Penelitian Kualitatif Paradigma Baru Ilmu Komunikasi dan Ilmu Sosial Lainnya, Bandung: PT. Remaja Rosdakarya

Morissan. 2010. Psikologi Komunikasi, Bogor: Ghalia Indonesia.

Sugiyono. 2013. Metode Penelitian Kuantitatif Kualitatif dan $R \& D$, Bandung: Alfabeta 
Wahib, Abdul. 2015. Konsep Orang Tua dalam Membangun Kepribadian Anak, Artikel Jurnal Paradigma Volume 2, Nomor 1, 02. November 2015. 